
\title{
$\begin{array}{ll}\text { Research Square } & \begin{array}{l}\text { Preprints are preliminary reports that have not undergone peer review. } \\ \text { They should not be considered conclusive, used to inform clinical practice, } \\ \text { or referenced by the media as validated information. }\end{array}\end{array}$
}

\section{The Effect of Levetiracetam Treatment on Survival in Patients with Glioblastoma: A Systematic Review and Meta-Analysis.}

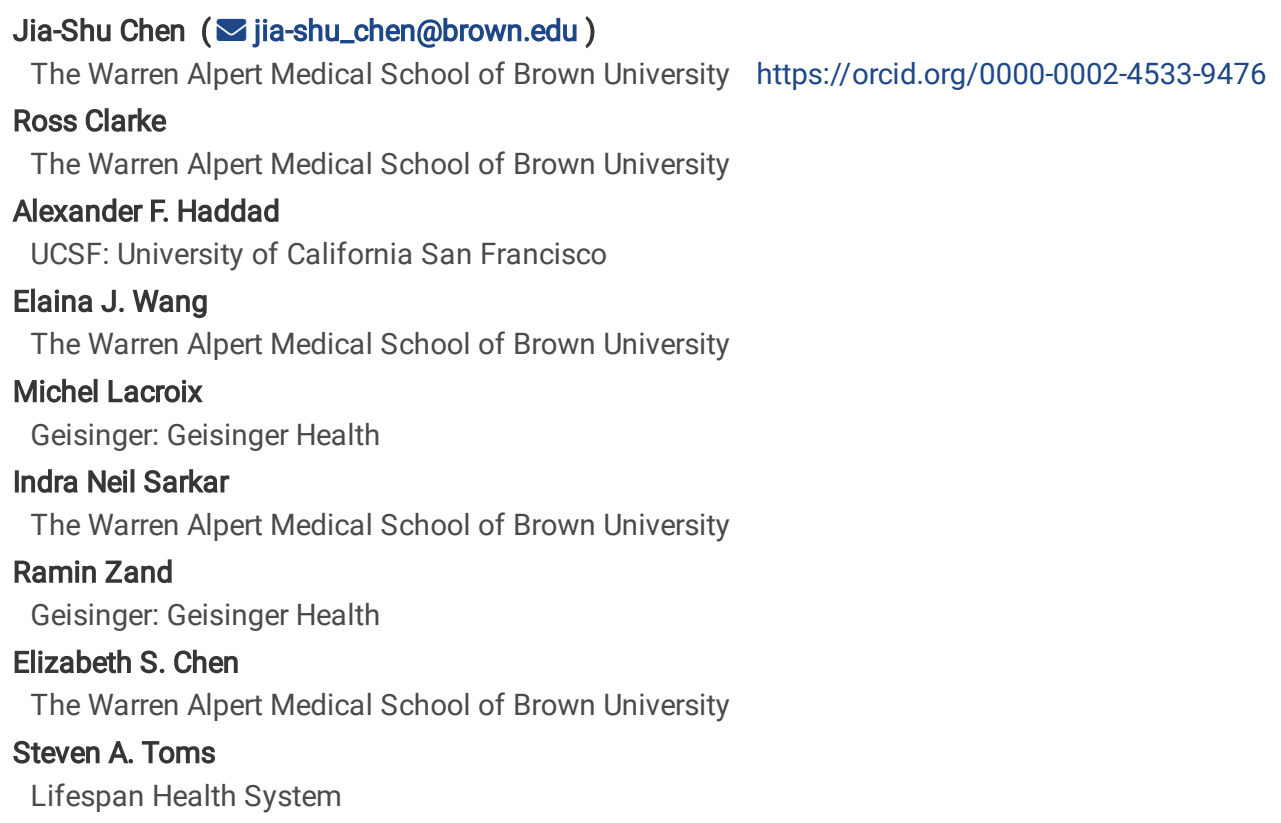

Research Article

Keywords: Anti-epileptic, Glioblastoma, Levetiracetam, Survival, Temozolomide

Posted Date: December 28th, 2021

DOl: https://doi.org/10.21203/rs.3.rs-945912/v1

License: (c) (i) This work is licensed under a Creative Commons Attribution 4.0 International License. Read Full License

Version of Record: A version of this preprint was published at Journal of Neuro-Oncology on January 4th, 2022. See the published version at https://doi.org/10.1007/s11060-021-03940-2. 


\section{Abstract}

\section{Background:}

Levetiracetam (LEV) is an anti-epileptic drug (AED) that sensitizes glioblastoma (GBM) to temozolomide (TMZ) chemotherapy by inhibiting $0^{6}$ methylguanine-DNA methyltransferase (MGMT) expression. Adding LEV to the standard of care (SOC) for GBM may improve TMZ efficacy. This study aimed to pool the existing evidence in the literature to quantify LEV's effect on GBM survival and characterize its safety profile to determine whether incorporating LEV into the SOC is warranted.

\section{Method:}

A search of CINAHL, Embase, PubMed, and Web of Science from inception to May 2021 was performed to identify relevant articles. Hazard ratios (HR), median overall survival, and adverse events were pooled using random-effect models. Meta-regression, funnel plots, and the Newcastle-Ottawa Scale were utilized to identify sources of heterogeneity, bias, and statistical influence.

\section{Results:}

From 20 included studies, 5804 GBM patients underwent meta-analysis, of which 1923 (33\%) were treated with LEV. Administration of LEV did not significantly improve survival in the entire patient population ( $\mathrm{HR}=0.89, p=0.094)$. Significant heterogeneity was observed during pooling of HRs $\left(P^{2}=75 \%, p<0.01\right)$. Meta-regression determined that LEV treatment effect decreased with greater rates of MGMT methylation $(\mathrm{RC}=0.03, p=0.02)$ and increased with greater proportions of female patients $(\mathrm{RC}=-0.05, p=0.002)$. Concurrent LEV with the SOC for GBM did not increase odds of adverse events relative to other AEDs.

\section{Conclusions:}

Levetiracetam treatment may not be effective for all GBM patients. Instead, LEV may be better suited for treating specific molecular profiles of GBM. Further studies are necessary to identify optimal GBM candidates for LEV.

\section{Introduction}

Glioblastoma (GBM) is the most common and malignant primary tumor of the central nervous system [1]. The standard of care (SOC) for GBM involves cytoreductive surgery followed by adjuvant radiotherapy plus concomitant and maintenance temozolomide (TMZ) chemotherapy [2]. Despite an optimized protocol, GBM prognosis remains poor. Median overall survival (OS) is only $\sim 15$ months due to inevitable recurrence at $\sim 7$ months $[2,3]$. Some trials for tumor treating fields (TTF) and vaccine immunotherapy have observed notable improvements in survival relative to the SOC [3-5]. However, long-term survival remains unchanged, with few (4\%) surviving past five years [6, 7]. Furthermore, no additions to the SOC have been made despite many studies on diverse agents, highlighting the need for new therapeutic strategies [8].

The $0^{6}$-methylguanine-DNA methyltransferase (MGMT) gene encodes a DNA-repair protein that abrogates the effects of TMZ by removing TMZinduced alkyl groups from the $0^{6}$-position of guanine, a site that triggers apoptosis when alkylated [9-11]. Methylation of the MGMT promoter causes epigenetic silencing of the gene and is associated with longer OS when present in GBM patients receiving TMZ [12]. Accordingly, MGMT methylation is a robust predictor of OS in GBM given its TMZ-enhancing effects [13]. However, methylation is not universal, with frequency ranging from 19-68\% [14]. Given this variability, there is interest in identifying agents that can inactivate MGMT and be combined with TMZ to increase its anticancer potency $[15,16]$.

Levetiracetam (LEV) is a relatively new anti-epileptic drug that recently became one of the most commonly prescribed drugs for seizures in patients with brain tumors [17]. This trend is attributed to LEV's favorable pharmacokinetic profile that includes optimal bioavailability, minimal plasma protein binding, and faster steady-state concentrations, plus the fact that it does not induce cytochrome P450 enzymes, which degrade chemotherapeutics $[18,19]$. However, clinical benefits of LEV may not be limited to seizure control. Studies have reported that LEV inhibits MGMT transcription in GBM via a p53-mediated corepressor complex of mSin3A and HDAC1 and enhances apoptosis with TMZ [20, 21]. Retrospective studies have shown promising survival benefits in GBM patients treated with LEV [22-24]. However, single-institution reviews are subject to biases from small sample sizes, patient selection, and variations in clinical practice that create non-generalizable results [25]. Furthermore, greater investigation has generated contrary findings, making it unclear whether LEV is a viable strategy [26]. Without a randomized controlled trial (RCT), a systematic review that pools the published evidence may provide the most clinical insight by mitigating limitations of retrospective studies and overcoming inter-study heterogeneity. Thus, this study was performed to systematically summarize the existing literature to: (1) determine whether LEV has a clinically generalizable survival impact and (2) describe the safety profile of LEV in patients with GBM.

\section{Methods}

This study was performed and is reported according to PRISMA guidelines under the supervision of an expert informatician (I.N.S.) with training in library and information science [27]. 


\section{Search Strategy}

A comprehensive literature search of CINAHL, Embase, PubMed, and Web of Science from inception to May 22nd, 2021 was performed using a search strategy designed with permutations of the following search terms and their variations: "Levetiracetam", "Glioblastoma", "Survival", and "Side Effect." The complete search strategy and its results are available in the Supplementary Materials.

\section{Study Selection}

Review of articles from the search strategy for inclusion occurred in two stages by two authors (J.C., R.C.) within Rayyan [28]. First, reviewers independently screened titles and abstracts of all articles to identify relevant studies. Duplicate articles were simultaneously screened and consolidated. Next, reviewers independently performed a full-text review of relevant studies using the criteria below to determine whether studies should proceed to meta-analysis. Cohen's kappa was calculated to evaluate strength of agreement, using the following thresholds for interpretation: $<0.20$ as slight, 0.21-0.40 as fair, 0.41-0.60 as moderate, 0.61-0.80 as substantial, and 0.81-1.00 as near perfect agreement [29].

\section{Eligibility Criteria}

Inclusion and exclusion criteria were established a priori. In order to include an article, the study needed to meet all of the following: (1) utilize casecontrol, cohort study, or RCT methodology; (2) focus on primary GBM patients; (3) stratify by LEV treatment; and, (4) report estimates describing survival outcomes or adverse events.

Articles were excluded if any of the following were met: (1) is a case report or review paper; (2) focuses on GBM cases not treated with surgery, recurrent GBM, or pediatric patients; (3) does not stratify by GBM diagnosis and LEV treatment; or, (4) does not report relevant outcomes on survival or adverse events. If a cohort was used to publish multiple studies on the same outcome, only the most complete report was included.

\section{Data Extraction}

Outcomes were abstracted from included studies by one author (J.C.). The following information was extracted when available: publication year, study design, number of patients treated with LEV, gender distribution, mean or median age at diagnosis, percentage of patients with MGMT methylation, percentage of patients who received gross total resection, TMZ, and the Stupp protocol, follow-up duration, hazard ratio (HR) comparing time-to-death between LEV and no LEV cohorts, median OS, and type and number of adverse events with LEV or other AED.

\section{Quality Appraisal}

The quality of each study was graded by one author (J.C.) using the Newcastle-Ottawa Scale (NOS) [30]. The NOS evaluates the quality and risk of bias by generating a quantitative score based on study type, selection of study cohort, comparability of participants, and adequacy of outcome metrics. A maximum score of 9 can be given, and the score was qualitatively categorized as poor (0-3), fair (4-6), or good (7+). Given the median survival with GBM under the Stupp protocol, adequate follow-up was defined as a mean or median follow-up of at least 15 months.

\section{Statistical Analysis}

Descriptive statistics were used to characterize the population of included articles. Categorical variables were reported using frequency and proportions. Continuous variables were described with median or mean and range. Pooling of HRs, difference in median survival, proportion of adverse events, and odds ratios (OR) was accomplished by using the inverse variance method for calculating weights and the DerSimonian-Laird random-effects modeling approach for estimating the overall study statistic to account for variability from clinical diversity and methodological variation between studies [31]. This was accomplished by assuming unequal variance and distributing statistical weighting more conservatively. Heterogeneity across studies was evaluated using the Higgins and Thompson's $P$ statistic, with an $R \geq 75 \%$ being considered significantly heterogenous [32]. Meta-regression was performed to identify potential sources of heterogeneity in the pooled data by analyzing how LEV treatment effect correlates with study year and design, age at diagnosis, gender, MGMT methylation, extent of resection, and adjuvant treatment regimen. Publication bias was evaluated using funnel plots of the treatment effect against variance and assessing for asymmetry. A two-tailed $p$-value $<0.05$ was the threshold for statistical significance. All statistical analyses were performed in RStudio (RStudio, Inc., Version 1.2.1335).

\section{Results}

\section{Study Selection}

A total of 3509 citations were initially identified. After removing 927 duplicates, 2582 articles underwent title and abstract screening, of which 2340 were excluded. Full-text review of 242 studies led to the inclusion of 20 for meta-analysis. Two included articles reported findings using the same cohort of GBM patients [33,34]. Both studies were included because one assessed survival outcomes [33], while the other detailed adverse events [34]. The sample size of these articles was only counted once. Interrater reliability was near perfect (Cohen's Kappa=0.82). The selection process is outlined in Figure 1.

\section{Study Characteristics}


The 20 included articles were published between 2006-2021, and their characteristics are listed in Table 1. Eleven (55\%) were used to evaluate LEV's impact on survival [22-24, 26, 33, 35-40], while 12 (60\%) were used to characterize the safety profile of administering LEV with the SOC in GBM [34, $37,38,41-48]$. Most articles were retrospective observational cohort studies (60\%). However, there were seven (35\%) prospective studies, one that was a randomized trial with data on adverse events, and one that was a post-hoc analysis of RCTs for treatments unrelated to LEV. Overall, 5804 patients were included, of which 1923 (33\%) received LEV. 
Table 1

Characteristics of all included studies.

\begin{tabular}{|c|c|c|c|c|c|c|c|c|c|c|c|}
\hline Study & Location & $\begin{array}{l}\text { Study } \\
\text { Design }^{a}\end{array}$ & $\begin{array}{l}\text { Cohort Size } \\
\text { (LEV/no } \\
\text { LEV) }\end{array}$ & $\begin{array}{l}\text { Female } \\
(n, \%)\end{array}$ & $\begin{array}{l}\text { Age } \\
\text { (years) }\end{array}$ & $\begin{array}{l}\text { MGMT } \\
\text { Methylated } \\
(\mathrm{n}, \%)\end{array}$ & $\begin{array}{l}\text { GTR } \\
(n, \%)\end{array}$ & $\begin{array}{l}\text { TMZ } \\
(n, \%)\end{array}$ & $\begin{array}{l}\text { TMZ + } \\
\text { RT } \\
(n, \%)\end{array}$ & $\begin{array}{l}\text { FU } \\
\text { (months) }\end{array}$ & $\begin{array}{l}\text { Outcomes } \\
\text { Reported }\end{array}$ \\
\hline $\begin{array}{l}\text { Barker } \\
(2013)\end{array}$ & USA & $\begin{array}{l}\text { R OCS } \\
\text { (1) }\end{array}$ & $\begin{array}{l}531 \\
(92 / 439)\end{array}$ & $\begin{array}{l}189 \\
(36 \%)\end{array}$ & $\begin{array}{l}56(18- \\
70)^{b}\end{array}$ & NR & $\begin{array}{l}212 \\
(40 \%)\end{array}$ & $\begin{array}{l}185 \\
(35 \%)\end{array}$ & $\begin{array}{l}185 \\
(35 \%)\end{array}$ & NR & $\mathrm{HR}$ \\
\hline $\begin{array}{l}\text { Berendsen } \\
\text { (2016) }\end{array}$ & Netherlands & $\begin{array}{l}\text { R OCS } \\
\text { (1) }\end{array}$ & $\begin{array}{l}647 \\
(92 / 555)\end{array}$ & $\begin{array}{l}260 \\
(40 \%)\end{array}$ & NR & NR & $\begin{array}{l}424 \\
(66 \%)\end{array}$ & NR & $\begin{array}{l}332 \\
(51 \%)\end{array}$ & NR & $\mathrm{HR}$ \\
\hline $\begin{array}{l}\text { Cardona } \\
\text { (2018) }\end{array}$ & Colombia & $\begin{array}{l}\text { P OCS } \\
(1)\end{array}$ & $\begin{array}{l}213 \\
(78 / 135)\end{array}$ & $\begin{array}{l}92 \\
(43 \%)\end{array}$ & $\begin{array}{l}\text { NR } \\
(17- \\
84)\end{array}$ & $59(28 \%)$ & $\begin{array}{l}136 \\
(64 \%)\end{array}$ & $\begin{array}{l}213 \\
(100 \%)\end{array}$ & $\begin{array}{l}213 \\
(100 \%)\end{array}$ & NR & $\begin{array}{l}\text { AE; HR; } \\
\text { mOS }\end{array}$ \\
\hline $\begin{array}{l}\text { Dinapoli } \\
(2009)\end{array}$ & Italy & $\begin{array}{l}\text { R OCS } \\
\text { (1) }\end{array}$ & $3(3 / 0)$ & $\begin{array}{l}1 \\
(33 \%)\end{array}$ & $\begin{array}{l}64(44- \\
67)^{b}\end{array}$ & NR & $\begin{array}{l}2 \\
(66 \%)\end{array}$ & $\begin{array}{l}3 \\
(100 \%)\end{array}$ & $\begin{array}{l}1 \\
(33 \%)\end{array}$ & $6(6-6)^{b}$ & $\mathrm{AE}$ \\
\hline $\begin{array}{l}\text { Fuller } \\
\text { (2013) }\end{array}$ & Australia & $\begin{array}{l}\text { P RCT } \\
\text { (1) }\end{array}$ & $13(7 / 6)$ & NR & NR & NR & NR & NR & NR & NR & $\mathrm{AE}$ \\
\hline $\begin{array}{l}\text { Happold } \\
(2016)\end{array}$ & Europe; NA & P RCT & $\begin{array}{l}1582 \\
(541 / 1041)\end{array}$ & $\begin{array}{l}644 \\
(41 \%)\end{array}$ & $\begin{array}{l}57(18- \\
82)^{b}\end{array}$ & $750(47 \%)$ & $\begin{array}{l}782 \\
(49 \%)\end{array}$ & $\begin{array}{l}1582 \\
(100 \%)\end{array}$ & $\begin{array}{l}1582 \\
(100 \%)\end{array}$ & NR & HR; mOS \\
\hline Kim (2015) & Korea & $\begin{array}{l}\text { R OCS } \\
\text { (1) }\end{array}$ & $\begin{array}{l}103 \\
(58 / 45)\end{array}$ & $\begin{array}{l}51 \\
(50 \%)\end{array}$ & $\begin{array}{l}59(18- \\
84)^{b}\end{array}$ & $28(27 \%)$ & $\begin{array}{l}65 \\
(63 \%)\end{array}$ & $\begin{array}{l}103 \\
(100 \%)\end{array}$ & $\begin{array}{l}103 \\
(100 \%)\end{array}$ & $\begin{array}{l}17(3-72) \\
b\end{array}$ & HR; mOS; \\
\hline $\begin{array}{l}\text { Knudsen- } \\
\text { Baas } \\
(2016)\end{array}$ & Norway & R OCS & $\begin{array}{l}1263 \\
(195 / 1068)\end{array}$ & $\begin{array}{l}532 \\
(42 \%)\end{array}$ & NR & NR & NR & $\begin{array}{l}721 \\
(57 \%)\end{array}$ & $\begin{array}{l}663 \\
(52 \%)\end{array}$ & NR & $\mathrm{HR}$ \\
\hline $\begin{array}{l}\text { Knudsen- } \\
\text { Baas } \\
(2018)\end{array}$ & Norway & R OCS & $\begin{array}{l}1263 \\
(195 / 1068)\end{array}$ & $\begin{array}{l}532 \\
(42 \%)\end{array}$ & NR & NR & NR & $\begin{array}{l}721 \\
(57 \%)\end{array}$ & $\begin{array}{l}663 \\
(52 \%)\end{array}$ & NR & $\mathrm{AE}$ \\
\hline $\begin{array}{l}\text { Knudsen- } \\
\text { Baas } \\
(2021)\end{array}$ & $\begin{array}{l}\text { Italy; } \\
\text { Norway }\end{array}$ & $\begin{array}{l}\text { R OCS } \\
\text { (3) }\end{array}$ & $\begin{array}{l}100 \\
(71 / 29)\end{array}$ & $\begin{array}{l}28 \\
(28 \%)\end{array}$ & $\begin{array}{l}54(26- \\
85)^{b}\end{array}$ & $46(46 \%)$ & $\begin{array}{l}48 \\
(48 \%)\end{array}$ & $\begin{array}{l}90 \\
(90 \%)\end{array}$ & $\begin{array}{l}89 \\
(89 \%)\end{array}$ & $\begin{array}{l}17(3- \\
145)^{b}\end{array}$ & $A E ; H R$ \\
\hline $\begin{array}{l}\text { Maschio } \\
(2006)\end{array}$ & Italy & $\begin{array}{l}\text { P OCS } \\
(1)\end{array}$ & $7(7 / 0)$ & $\begin{array}{l}2 \\
(29 \%)\end{array}$ & $\begin{array}{l}63(40- \\
70)^{b}\end{array}$ & NR & $\begin{array}{l}1 \\
(14 \%)\end{array}$ & $\begin{array}{l}7 \\
(100 \%)\end{array}$ & $0(0 \%)$ & $\begin{array}{l}20(9-31) \\
b\end{array}$ & $\mathrm{AE}$ \\
\hline $\begin{array}{l}\text { Maschio } \\
(2011)\end{array}$ & Italy & $\begin{array}{l}\text { P OCS } \\
\text { (1) }\end{array}$ & $9(9 / 0)$ & $\begin{array}{l}4 \\
(44 \%)\end{array}$ & $\begin{array}{l}67(44- \\
75)^{\mathrm{b}}\end{array}$ & NR & $\begin{array}{l}5 \\
(56 \%)\end{array}$ & $\begin{array}{l}9 \\
(100 \%)\end{array}$ & $\begin{array}{l}9 \\
(100 \%)\end{array}$ & NR & $\mathrm{AE}$ \\
\hline $\begin{array}{l}\text { Newton } \\
\text { (2006) }\end{array}$ & USA & $\begin{array}{l}\text { R OCS } \\
\text { (1) }\end{array}$ & $12(12 / 0)$ & NR & NR & NR & NR & NR & NR & NR & $\mathrm{AE}$ \\
\hline $\begin{array}{l}\text { Rigamonti } \\
(2018)\end{array}$ & Italy & $\begin{array}{l}\text { R OCS } \\
\text { (3) }\end{array}$ & $\begin{array}{l}235 \\
(119 / 116)\end{array}$ & $\begin{array}{l}89 \\
(38 \%)\end{array}$ & $\begin{array}{l}66(28- \\
83)^{b}\end{array}$ & NR & $\begin{array}{l}197 \\
(69 \%)\end{array}$ & $\begin{array}{l}176 \\
(75 \%)\end{array}$ & $\begin{array}{l}176 \\
(75 \%)\end{array}$ & $\begin{array}{l}37.2 \\
(N R)^{b}\end{array}$ & $\mathrm{HR}$ \\
\hline Roh (2020) & Korea & $\begin{array}{l}\text { R OCS } \\
\text { (1) }\end{array}$ & $\begin{array}{l}322 \\
(169 / 153)\end{array}$ & $\begin{array}{l}141 \\
(44 \%)\end{array}$ & $\begin{array}{l}58(19- \\
79)^{b}\end{array}$ & 87 (29\%) & $\begin{array}{l}171 \\
(53 \%)\end{array}$ & $\begin{array}{l}322 \\
(100 \%)\end{array}$ & $\begin{array}{l}322 \\
(100 \%)\end{array}$ & $\begin{array}{l}60.8 \\
(N R)^{b}\end{array}$ & $\mathrm{HR} ; \mathrm{mOS}$ \\
\hline Ryu (2019) & Korea & $\begin{array}{l}\text { R OCS } \\
\text { (1) }\end{array}$ & $\begin{array}{l}418 \\
(322 / 96)\end{array}$ & $\begin{array}{l}188 \\
(45 \%)\end{array}$ & $\begin{array}{l}57(2- \\
82)^{b}\end{array}$ & 70 (17\%) & NR & $\begin{array}{l}418 \\
(100 \%)\end{array}$ & $\begin{array}{l}418 \\
(100 \%)\end{array}$ & NR & $\begin{array}{l}\mathrm{AE} ; \mathrm{HR} ; \\
\mathrm{mOS}\end{array}$ \\
\hline $\begin{array}{l}\text { Simo } \\
(2012)\end{array}$ & Spain & $\begin{array}{l}\text { P OCS } \\
(2)\end{array}$ & $\begin{array}{l}101 \\
(31 / 70)\end{array}$ & $\begin{array}{l}32 \\
(32 \%)\end{array}$ & $\begin{array}{l}57 \\
(N R)^{c}\end{array}$ & NR & $\begin{array}{l}49 \\
(48 \%)\end{array}$ & $\begin{array}{l}101 \\
(100 \%)\end{array}$ & $\begin{array}{l}101 \\
(100 \%)\end{array}$ & NR & $\mathrm{HR} ; \mathrm{mOS}$ \\
\hline $\begin{array}{l}\text { Toledo } \\
\text { (2017) }\end{array}$ & Spain & $\begin{array}{l}\text { P OCS } \\
\text { (1) }\end{array}$ & $56(24 / 32)$ & $\begin{array}{l}24 \\
(43 \%)\end{array}$ & $\begin{array}{l}57(30- \\
77)^{c}\end{array}$ & NR & $\begin{array}{l}33 \\
(59 \%)\end{array}$ & $\begin{array}{l}56 \\
(100 \%)\end{array}$ & $\begin{array}{l}56 \\
(100 \%)\end{array}$ & NR & $\mathrm{AE}$ \\
\hline $\begin{array}{l}\text { Valko } \\
\text { (2015) }\end{array}$ & Switzerland & $\begin{array}{l}\text { P OCS } \\
\text { (1) }\end{array}$ & $65(21 / 44)$ & $\begin{array}{l}21 \\
(32 \%)\end{array}$ & $\begin{array}{l}57.3 \\
(N R)^{c}\end{array}$ & NR & $\begin{array}{l}14 \\
(22 \%)\end{array}$ & $0(0 \%)$ & $0(0 \%)$ & NR & $\mathrm{AE}$ \\
\hline
\end{tabular}

Abbreviations: AE Adverse Events; CT Clinical Trial; FUFollow-Up; HR Hazard Ratio; GTR Gross Total Resection; IPD Individual-Patient Data; LEV Levetiracetam; mOS Median Overall Survival; NA North America; NR Not Reported; OCS Observational Cohort Study; PProspective; $R$ Retrospective; RCT Randomized Clinical Trial; RT Radiotherapy; TMZ Temozolomide.

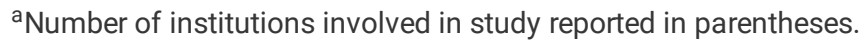

${ }^{\mathrm{b}}$ Median (range)

${ }^{\mathrm{c}}$ Mean (range) 


\begin{tabular}{|c|c|c|c|c|c|c|c|c|c|c|c|}
\hline Study & Location & $\begin{array}{l}\text { Study } \\
\text { Designa }\end{array}$ & $\begin{array}{l}\text { Cohort Size } \\
\text { (LEV/no } \\
\text { LEV) }\end{array}$ & $\begin{array}{l}\text { Female } \\
(n, \%)\end{array}$ & $\begin{array}{l}\text { Age } \\
\text { (years) }\end{array}$ & $\begin{array}{l}\text { MGMT } \\
\text { Methylated } \\
(n, \%)\end{array}$ & $\begin{array}{l}\text { GTR } \\
(n, \%)\end{array}$ & $\begin{array}{l}\text { TMZ } \\
(n, \%)\end{array}$ & $\begin{array}{l}\text { TMZ + } \\
\text { RT } \\
(n, \%)\end{array}$ & $\begin{array}{l}\text { FU } \\
\text { (months) }\end{array}$ & $\begin{array}{l}\text { Outcomes } \\
\text { Reported }\end{array}$ \\
\hline $\begin{array}{l}\text { Wychowski } \\
\text { (2013) }\end{array}$ & USA & $\begin{array}{l}\text { R OCS } \\
\text { (1) }\end{array}$ & $\begin{array}{l}124 \\
(72 / 52)\end{array}$ & NR & NR & NR & $\begin{array}{l}37 \\
(22 \%)\end{array}$ & NR & NR & NR & $\mathrm{AE}$ \\
\hline \multicolumn{12}{|c|}{$\begin{array}{l}\text { Abbreviations: AEAdverse Events; CT Clinical Trial; FUFollow-Up; HR Hazard Ratio; GTR Gross Total Resection; IPD Individual-Patient Data; LEV } \\
\text { Levetiracetam; } m \text { OS Median Overall Survival; NA North America; NR Not Reported; OCS Observational Cohort Study; P Prospective; } R \\
\text { Retrospective; RCT Randomized Clinical Trial; RT Radiotherapy; TMZ Temozolomide. }\end{array}$} \\
\hline \multicolumn{12}{|c|}{ 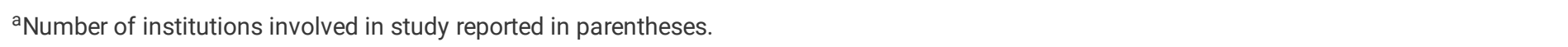 } \\
\hline \multicolumn{12}{|c|}{${ }^{\mathrm{b}}$ Median (range) } \\
\hline${ }^{\mathrm{c}}$ Mean (rang & & & & & & & & & & & \\
\hline
\end{tabular}

The majority of studies were graded as fair quality $(70 \%)$, while four $(20 \%)$ were good and two $(10 \%)$ were poor. Of the studies evaluated for survival impact, all were fair (64\%) or good (36\%) quality. Investigations on survival tended to have high risk of bias because the length and/or adequacy of follow-up could not be confirmed and, to a lesser degree, because survival comparisons were confined to a subset of patients and not generalizable. Of the studies contributing safety data, all but one were fair $(75 \%)$ or poor $(17 \%)$ quality. Similarly, most studies on adverse events had high bias due to inadequate follow-up or because the study cohort was not representative of the GBM patient population. Detailed scoring outlining the NOS criteria for each study is reported in Supplementary Table 1.

\section{Survival Meta-Analysis}

Of the 11 studies included in the survival meta-analysis, three reported a significant improvement in survival [22-24], five suggested a trend towards improved survival [35-37, 39, 40], and one published significantly worse survival outcomes with LEV treatment [38]. Pooling results from all 11 studies led to a pooled HR of $0.89(95 \%-\mathrm{Cl}=0.78-1.02)$ that trended towards significantly better survival in LEV patients $(p=0.094)$. Significant heterogeneity was observed $\left({ }^{2}=75 \%, p<0.01\right)$ during pooling (Figure $\left.2 A\right)$.

Median OS with $95 \%-\mathrm{Cl}$ was reported in six studies [22-24, 26, 37, 40]. The pooled median OS of the patients treated with LEV and no LEV was 22.9 $(95 \%-\mathrm{Cl}=21.2-24.7)$ and $16.8(95 \%-\mathrm{Cl}=15.1-18.6)$ months, respectively. The pooled difference in median OS between the LEV and no LEV treated cohorts was significant $(p<0.01)$ and estimated to be $6.21(95 \%-\mathrm{Cl}=2.75-9.66)$ months in favor of LEV treated patients. There was significant heterogeneity across the pooled studies $(F=100 \%, p<0.001)$ (Figure $2 \mathrm{~B})$.

On meta-regression analysis, publication year $(\mathrm{RC}=0.10,95 \%-\mathrm{Cl}=-0.06-0.08, p=0.75)$, retrospective study design $(\mathrm{RC}=-0.14,95 \%-\mathrm{Cl}=-0.47-0.18$, $p=0.38)$, age ( $\mathrm{RC}=-0.03,95 \%-\mathrm{Cl}=-0.11-0.04, p=0.37)$, gross total resection $(\mathrm{RC}=-0.01,95 \%-\mathrm{Cl}=-0.03-0.01, p=0.31)$, and percentage of patients treated with the Stupp protocol $(\mathrm{RC}=-0.003,95 \%-\mathrm{Cl}=-0.009-0.003, p=0.30)$ were not associated with $\mathrm{LEV}$ treatment effect. However, the percentage of MGMT methylated patients $(\mathrm{RC}=0.03,95 \%-\mathrm{Cl}=0.01-0.05, p=0.02)$ and female patients $(\mathrm{RC}=-0.05,95 \%-\mathrm{Cl}=[-0.08,-0.02], p=0.002)$ were both significantly associated with LEV treatment effect (Figure 3A). A greater rate of methylation was associated with less significant and larger HRs, while a greater proportion of female patients was correlated with more significant and smaller HRs. A funnel plot for the pooling of HRs depicted a slight asymmetry suggestive of potential publication bias against insignificant results opposing LEV efficacy (Figure 3B).

\section{Safety Meta-Analysis}

From the 12 studies that reported data on adverse events, the most commonly reported complications were somnolence [41, 44-46], fatigue [37, 47, $48]$, neuropsychiatric disturbances [23,34,37, 38, 42, 46, 48], and allergic reactions and/or skin rashes [23, 37, 38, 42]. The proportion of patients encountering an adverse event from LEV while being treated for GBM was pooled and determined to be $23 \%(95 \%-\mathrm{Cl}=13-32 \%)$. The heterogeneity across studies was significant $(R=94 \%, p<0.001)$ (Figure $4 A)$. The proportion of adverse events while being treated with LEV was compared to the proportion of complications under other AEDs, and the pooled OR was insignificant $(p=0.41)$, with LEV having comparable odds of adverse events relative to other AEDs (OR=0.79, 95\%-Cl=0.45-1.38) (Figure 4B).

\section{Discussion}

Identification of effective treatments that can safely accompany and work in tandem with the SOC is essential for improving the prognosis of GBM. Thus, in this systematic review and meta-analysis, we assessed the published literature to determine whether LEV, an AED reported to improve GBM prognosis, prolongs survival for GBM patients in a safe and generalizable manner.

Pooling of published HRs demonstrated that LEV does not have a significant effect on survival. While there was a trend towards longer survival, the pooled treatment effect was not statistically significant. Our findings contrast those of a recent retrospective study and meta-analysis by Jabbarli et al. that reported a significant survival benefit but did not grade the quality of evidence, assess for potential sources of heterogeneity or bias, or 
evaluate the safety of LEV with the SOC [49]. All the studies included in the aforementioned study were captured by our search strategy and selection process. However, we were also able to identify four additional investigations published between 2012-2021, two that were graded as "good" quality and two that were graded as "fair" [36, 38-40]. Of these four studies, none reported significantly improved survival, and one found LEV to be associated with significantly worse survival [38]. Furthermore, our assessment of publication bias using funnel plots indicated that results suggestive of LEV having an insignificant or deleterious impact on survival may be underreported. This was reaffirmed by two articles that found no survival benefit with LEV and were reviewed during our selection process but had to ultimately be excluded from meta-analysis because the authors did not report statistics that could be pooled $[46,50]$. Thus, the treatment effect reported by Jabbarli et al., and potentially this study, is likely overestimated and not as substantial as it is currently published for all patients with GBM.

While LEV may not have a survival impact on the entire GBM population, it is important to note that GBM is a highly heterogenous disease with several distinct molecular subtypes that vary in gene expression, tumor mutational burden, epigenetic modifications, and, consequently, treatment responses [51-53]. Our meta-analysis highlighted this by concluding that there was significant heterogeneity across our pooled studies. To evaluate potential sources of heterogeneity, we performed meta-regression to identify any correlations between demographics and treatment effect and found that MGMT methylation and sex had a significant correlation. Specifically, populations with a lower rate of MGMT methylation or larger proportion of female patients had more robust differences in survival following LEV treatment.

In the original study reporting on the cellular effects of LEV on GBM, Bobustuc et al. found that LEV enhances tumor cell apoptosis to TMZ by inhibiting MGMT expression. Given this mechanism of action, LEV's therapeutic efficacy may be enhanced in patients who are not methylated at the MGMT promoter, since those who are methylated will already have lower MGMT expression and experience the survival benefit associated with it [12]. Furthermore, sex differences in GBM incidence and survival are well reported, with being female consistently found to be associated with lower incidence and better outcome [54, 55]. More importantly, however, investigations into the potential mechanisms behind these sex differences have highlighted that increased incidence of GBM, tumorigenesis, and poor treatment responses in males is attributed to sexual dimorphism in the p53 pathway, specifically greater TP53 mutational burden and increased susceptibility to deregulated X-linked genes that negatively regulate p53 in males $[56,57]$. The second main finding in Bobustuc et al.'s original study was that LEV's inhibition of MGMT expression is dependent on the expression of p53, mSin3A, and HDAC1, meaning patients with reduced p53 viability, such as males, may not be positioned to experience the benefits of LEV treatment, as seen in our findings.

These results may highlight the potential limitations of LEV as a therapeutic modality; however, they do not encourage the abandonment of LEV as a therapy worth investigating. Instead, this study highlights the importance of first identifying the GBM patient population who should be actively sought out and targeted for adjuvant LEV treatment, in addition to those with epileptic seizures, before conducting an RCT as has been previously encouraged so that adequate controls and study designs are implemented to account for LEV's mechanism of action. Biomarker-driven patient selection is becoming increasingly important in the study design of clinical trials to ensure accurate conclusions, especially in a disease like GBM that is not only very heterogenous but has also experienced many clinical trial failures [58,59]. With our current trajectory towards greater utilization of personalized oncology treatments and molecular diagnoses, LEV could still have great potential for treating GBM even if only certain populations benefit, especially given its safety profile that was confirmed to be acceptable alongside the SOC in this study. Further studies correlating molecular and genomic data with the clinical effect of LEV are needed to confirm the trends identified in this study and ensure that a robust RCT study design is undertaken to truly determine whether LEV improves survival.

This review had several limitations. Although an exhaustive search strategy was designed and utilized, it is possible that relevant studies were not identified due to screening errors or inappropriate indexing. While most studies were "fair" or "good" quality, scores were most commonly marked down due to an inability to confirm the adequacy of follow-up. Given this, treatment effects may have been improperly estimated because too many patients were lost to follow-up or not followed for the appropriate duration. Furthermore, the topic of follow-up underscores another significant limitation known as protopathic bias. In this situation, a patient treated with LEV and another without may have had similar biological survival from tumor initiation to time of death. However, the patient with LEV may be documented as having longer clinical survival because their need to control seizures with LEV may have caused earlier diagnosis. Finally, while our study determined that MGMT methylation correlated with reduced LEV treatment effect, there is likely heterogeneity across studies in how methylated and unmethylated patients were categorized given that there is no universally-accepted test or consensus cut-off for MGMT status [60]. Future prospective studies will need to ensure that there is adequate follow-up, consistent MGMT status determination criteria, and properly matched and randomized patients.

\section{Conclusion}

This systematic review and meta-analysis determined that LEV can be safely delivered with the SOC for GBM but does not significantly improve survival in all patients. However, there was significant heterogeneity across studies, and meta-regression demonstrated that certain populations may benefit from LEV. Investigations using molecular and genetic sequencing data to identify patients most likely to benefit from LEV are needed to determine what additional populations with GBM should be actively considered for LEV treatment.

\section{Declarations}

Disclosures: No financial disclosures or conflicts of interest to report. 


\section{Author Contributions:}

Conception and Design: Jia-Shu Chen, Steven A. Toms; Acquisition of Data: Jia-Shu Chen, Ross Clarke; Statistical Analysis and Interpretation of Data: Jia-Shu Chen, Ramin Zand, Steven A. Toms; Drafting the Article: Jia-Shu Chen; Critical Review of the Article: All Authors; Approved Final Version of Manuscript: All Authors; Administrative/Technical/Material Support: Michel Lacroix, Indra Neil Sarkar, Ramin Zand, Elizabeth S. Chen, Steven A. Toms; Study Supervision: Steven A. Toms.

\section{Conflicts of Interests}

The authors report no conflicts of interest or funding sources concerning the materials and methods used in this study or the results and findings detailed in this paper.

\section{Data Availability}

The datasets generated and analyzed in the current study are available from the corresponding author on reasonable request.

\section{Ethical Approval}

This article does not contain any studies with human participants or animals performed by any of the authors.

\section{Informed Consent}

Informed consent was not required due to study design requiring no collection of data other than from the published literature.

\section{References}

1. Ostrom QT, Patil N, Cioffi G, Waite K, Kruchko C, Barnholtz-Sloan JS (2020) CBTRUS Statistical Report: Primary Brain and Other Central Nervous System Tumors Diagnosed in the United States in 2013-2017. Neuro Oncol 22: iv1-iv96 doi:10.1093/neuonc/noaa200

2. Stupp R, Mason WP, van den Bent MJ, Weller M, Fisher B, Taphoorn MJ, Belanger K, Brandes AA, Marosi C, Bogdahn U, Curschmann J, Janzer RC, Ludwin SK, Gorlia T, Allgeier A, Lacombe D, Cairncross JG, Eisenhauer E, Mirimanoff RO, European Organisation for R, Treatment of Cancer Brain T, Radiotherapy G, National Cancer Institute of Canada Clinical Trials G (2005) Radiotherapy plus concomitant and adjuvant temozolomide for glioblastoma. N Engl J Med 352: 987-996 doi:10.1056/NEJMoa043330

3. Marenco-Hillembrand L, Wijesekera O, Suarez-Meade P, Mampre D, Jackson C, Peterson J, Trifiletti D, Hammack J, Ortiz K, Lesser E, Spiegel M, Prevatt C, Hawayek M, Quinones-Hinojosa A, Chaichana KL (2020) Trends in glioblastoma: outcomes over time and type of intervention: a systematic evidence based analysis. J Neuro-Oncol 147: 297-307 doi:10.1007/s11060-020-03451-6

4. Stupp R, Taillibert S, Kanner A, Read W, Steinberg DM, Lhermitte B, Toms S, Idbaih A, Ahluwalia MS, Fink K, Di Meco F, Lieberman F, Zhu JJ, Stragliotto G, Tran DD, Brem S, Hottinger AF, Kirson ED, Lavy-Shahaf G, Weinberg U, Kim CY, Paek SH, Nicholas G, Burna J, Hirte H, Weller M, Palti Y, Hegi M, Ram Z (2017) Effect of Tumor-Treating Fields Plus Maintenance Temozolomide vs Maintenance Temozolomide Alone on Survival in Patients With Glioblastoma A Randomized Clinical Trial. Jama-J Am Med Assoc 318: 2306-2316 doi:10.1001/jama.2017.18718

5. Liau LM, Ashkan K, Tran DD, Campian JL, Trusheim JE, Cobbs CS, Heth JA, Salacz M, Taylor S, D'andre SD, Iwamoto FM, Dropcho EJ, Moshel YA, Walter KA, Pillainayagam CP, Aiken R, Chaudhary R, Goldlust SA, Bota DA, Duic P, Grewal J, Elinzano H, Toms SA, Lillehei KO, Mikkelsen T, Walpert T, Abram SR, Brenner AJ, Brem S, Ewend MG, Khagi S, Portnow J, Kim LJ, Loudon WG, Thompson RC, Avigan DE, Fink KL, Geofroy FJ, Lindhorst S, Lutzky J, Sloan AE, Schackert G, Krex D, Meisel HJ, Wu J, Davis RP, Duma C, Etame AB, Mathieu D, Kesari S, Piccioni D, Westphal M, Baskin DS, New PZ, Lacroix M, May SA, Pluard TJ, Tse V, Green RM, Villano JL, Pearlman M, Petrecca K, Schulder M, Taylor LP, Maida AE, Prins RM, Cloughesy TF, Mulholland P, Bosch ML (2018) First results on survival from a large Phase 3 clinical trial of an autologous dendritic cell vaccine in newly diagnosed glioblastoma. J Transl Med 16 doi:ARTN 142 10.1186/s12967-018-1507-6

6. Stupp R, Hegi ME, Mason WP, van den Bent MJ, Taphoorn MJB, Janzer RC, Ludwin SK, Allgeier A, Fisher B, Belanger K, Hau P, Brandes AA, Gijtenbeek J, Marosi C, Vecht CJ, Mokhtari K, Wesseling P, Villa S, Eisenhauer E, Gorlia T, Weller M, Lacombe D, Cairncross JG, Mirimanoff RO, Treatment EOR, Grp CBT, Grp RO, Trials NCICC (2009) Effects of radiotherapy with concomitant and adjuvant temozolomide versus radiotherapy alone on survival in glioblastoma in a randomised phase III study: 5-year analysis of the EORTC-NCIC trial. Lancet Oncol 10: 459-466 doi:10.1016/S1470-2045(09)70025-7

7. Poon MTC, Sudlow CLM, Figueroa JD, Brennan PM (2020) Longer-term (>= 2 years) survival in patients with glioblastoma in population-based studies pre- and post-2005: a systematic review and meta-analysis. Sci Rep-Uk 10 doi:10.1038/s41598-020-68011-4

8. Cantrell JN, Waddle MR, Rotman M, Peterson JL, Ruiz-Garcia H, Heckman MG, Quinones-Hinojosa A, Rosenfeld SS, Brown PD, Trifiletti DM (2019) Progress Toward Long-Term Survivors of Glioblastoma. Mayo Clin Proc 94: 1278-1286 doi:10.1016/j.mayocp.2018.11.031

9. Sedgwick B, Lindahl T (1982) A common mechanism for repair of O6-methylguanine and 06-ethylguanine in DNA. J Mol Biol 154: 169-175 doi:10.1016/0022-2836(82)90424-7 
10. Friedman HS, McLendon RE, Kerby T, Dugan M, Bigner SH, Henry AJ, Ashley DM, Krischer J, Lovell S, Rasheed K, Marchev F, Seman AJ, Cokgor I, Rich J, Stewart E, Colvin OM, Provenzale JM, Bigner DD, Haglund MM, Friedman AH, Modrich PL (1998) DNA mismatch repair and O6alkylguanine-DNA alkyltransferase analysis and response to Temodal in newly diagnosed malignant glioma. J Clin Oncol 16: $3851-3857$ doi:10.1200/JC0.1998.16.12.3851

11. Ochs K, Kaina B (2000) Apoptosis induced by DNA damage 0-6-methylguanine is Bcl-2 and caspase-9/3 regulated and Fas/caspase-8 independent. Cancer Res 60: 5815-5824

12. Hegi ME, Diserens AC, Gorlia T, Hamou MF, de Tribolet N, Weller M, Kros JM, Hainfellner JA, Mason W, Mariani L, Bromberg JE, Hau P, Mirimanoff RO, Cairncross JG, Janzer RC, Stupp R (2005) MGMT gene silencing and benefit from temozolomide in glioblastoma. N Engl J Med 352: 9971003 doi:10.1056/NEJMoa043331

13. Hegi ME, Diserens AC, Godard S, Dietrich PY, Regli L, Ostermann S, Otten P, Van Melle G, de Tribolet N, Stupp R (2004) Clinical trial substantiates the predictive value of 0-6-methylguanine-DNA methyltransferase promoter methylation in glioblastoma patients treated with temozolomide. Clin Cancer Res 10: 1871-1874 doi:10.1158/1078-0432.ccr-03-0384

14. Weller M, Stupp R, Reifenberger G, Brandes AA, van den Bent MJ, Wick W, Hegi ME (2010) MGMT promoter methylation in malignant gliomas: ready for personalized medicine? Nat Rev Neurol 6: 39-51 doi:10.1038/nrneurol.2009.197

15. Nakada M, Furuta T, Hayashi Y, Minamoto T, Hamada J (2012) The strategy for enhancing temozolomide against malignant glioma. Front Oncol 2: 98 doi:10.3389/fonc. 2012.00098

16. Yu W, Zhang L, Wei Q, Shao A (2019) O(6)-Methylguanine-DNA Methyltransferase (MGMT): Challenges and New Opportunities in Glioma Chemotherapy. Front Oncol 9: 1547 doi:10.3389/fonc.2019.01547

17. Dewan MC, Thompson RC, Kalkanis SN, Barker FG, 2nd, Hadjipanayis CG (2017) Prophylactic antiepileptic drug administration following brain tumor resection: results of a recent AANS/CNS Section on Tumors survey. J Neurosurg 126: 1772-1778 doi:10.3171/2016.4.JNS16245

18. Patsalos PN (2004) Clinical pharmacokinetics of levetiracetam. Clin Pharmacokinet 43: 707-724 doi:10.2165/00003088-200443110-00002

19. Oberndorfer S, Piribauer M, Marosi C, Lahrmann H, Hitzenberger P, Grisold W (2005) P450 enzyme inducing and non-enzyme inducing antiepileptics in glioblastoma patients treated with standard chemotherapy. J Neurooncol 72: 255-260 doi:10.1007/s11060-004-2338-2

20. Bobustuc GC, Baker CH, Limaye A, Jenkins WD, Pearl G, Avgeropoulos NG, Konduri SD (2010) Levetiracetam enhances p53-mediated MGMT inhibition and sensitizes glioblastoma cells to temozolomide. Neuro Oncol 12: 917-927 doi:10.1093/neuonc/noq044

21. Scicchitano BM, Sorrentino S, Proietti G, Lama G, Dobrowolny G, Catizone A, Binda E, Larocca LM, Sica G (2018) Levetiracetam enhances the temozolomide effect on glioblastoma stem cell proliferation and apoptosis. Cancer Cell Int 18: 136 doi:10.1186/s12935-018-0626-8

22. Kim YH, Kim T, Joo JD, Han JH, Kim YJ, Kim IA, Yun CH, Kim CY (2015) Survival benefit of levetiracetam in patients treated with concomitant chemoradiotherapy and adjuvant chemotherapy with temozolomide for glioblastoma multiforme. Cancer-Am Cancer Soc 121: 2926-2932 doi:10.1002/cncr.29439

23. Ryu JY, Min KL, Chang MJ (2019) Effect of anti-epileptic drugs on the survival of patients with glioblastoma multiforme: A retrospective, singlecenter study. PLoS One 14: e0225599 doi:10.1371/journal.pone.0225599

24. Roh TH, Moon JH, Park HH, Kim EH, Hong CK, Kim SH, Kang SG, Chang JH (2020) Association between survival and levetiracetam use in glioblastoma patients treated with temozolomide chemoradiotherapy. Sci Rep-Uk 10 doi:ARTN 10783 10.1038/s41598-020-67697-w

25. Sedgwick P (2014) Retrospective cohort studies: advantages and disadvantages. Bmj-Brit Med J 348 doi:ARTN g1072 10.1136/bmj.g1072

26. Happold C, Gorlia T, Chinot O, Gilbert MR, Nabors LB, Wick W, Pugh SL, Hegi M, Cloughesy T, Roth P, Reardon DA, Perry JR, Mehta MP, Stupp R, Weller M (2016) Does Valproic Acid or Levetiracetam Improve Survival in Glioblastoma? A Pooled Analysis of Prospective Clinical Trials in Newly Diagnosed Glioblastoma. J Clin Oncol 34: 731-+ doi:10.1200/Jco.2015.63.6563

27. Page MJ, McKenzie JE, Bossuyt PM, Boutron I, Hoffmann TC, Mulrow CD, Shamseer L, Tetzlaff JM, Akl EA, Brennan SE, Chou R, Glanville J, Grimshaw JM, Hrobjartsson A, Lalu MM, Li T, Loder EW, Mayo-Wilson E, McDonald S, McGuinness LA, Stewart LA, Thomas J, Tricco AC, Welch VA, Whiting P, Moher D (2021) The PRISMA 2020 statement: an updated guideline for reporting systematic reviews. BMJ 372 : n71 doi:10.1136/bmj.n71

28. Ouzzani M, Hammady H, Fedorowicz Z, Elmagarmid A (2016) Rayyan-a web and mobile app for systematic reviews. Syst Rev 5: 210 doi:10.1186/s13643-016-0384-4

29. McHugh ML (2012) Interrater reliability: the kappa statistic. Biochem Med (Zagreb) 22: 276-282

30. Wells G, Shea B, O'Connell D, Peterson J, Welch V, Losos M, Tugwell P (2016) The Newcastle-Ottawa Scale (NOS) for assessing the quality of nonrandomised studies in meta-analyses. Ottawa Hospital Research Institute, Ottawa (ON)

31. DerSimonian R, Laird N (1986) Meta-analysis in clinical trials. Control Clin Trials 7: 177-188 doi:10.1016/0197-2456(86)90046-2

32. Higgins JP, Thompson SG, Deeks JJ, Altman DG (2003) Measuring inconsistency in meta-analyses. BMJ 327: 557-560 doi:10.1136/bmj.327.7414.557

33. Knudsen-Baas KM, Engeland A, Gilhus NE, Storstein AM, Owe JF (2016) Does the choice of antiepileptic drug affect survival in glioblastoma patients? J Neuro-Oncol 129: 461-469 doi:10.1007/s11060-016-2191-0 
34. Knudsen-Baas KM, Johannesen TB, Myklebust TA, Aarseth JH, Owe JF, Gilhus NE, Storstein AM (2018) Antiepileptic and psychiatric medication in a nationwide cohort of patients with glioma WHO grade II-IV. J Neuro-Oncol 140: 739-748 doi:10.1007/s11060-018-03007-9

35. Barker CA, Bishop AJ, Chang M, Beal K, Chan TA (2013) Valproic Acid Use During Radiation Therapy for Glioblastoma Associated With Improved Survival. Int J Radiat Oncol 86: 504-509 doi:10.1016/j.ijrobp.2013.02.012

36. Berendsen S, Varkila M, Kroonen J, Seute T, Snijders TJ, Kauw F, Spliet WGM, Willems M, Poulet C, Broekman ML, Bours V, Robe PA (2016) Prognostic relevance of epilepsy at presentation in glioblastoma patients. Neuro-Oncology 18: 700-706 doi:10.1093/neuonc/nov238

37. Cardona AF, Rojas L, Wills B, Bernal L, Ruiz-Patino A, Arrieta O, Hakim EJ, Hakim F, Mejia JA, Useche N, Bermudez S, Carranza H, Vargas C, Otero J, Mayor LC, Ortiz LD, Franco S, Ortiz C, Gil-Gil M, Balana C, Zatarain-Barron ZL (2018) Efficacy and safety of Levetiracetam vs. other antiepileptic drugs in Hispanic patients with glioblastoma. J Neuro-Oncol 136: 363-371 doi:10.1007/s11060-017-2660-0

38. Knudsen-Baas KM, Storstein AM, Zarabla A, Maialetti A, Giannarelli D, Beghi E, Maschio M (2021) Antiseizure medication in patients with Glioblastoma- a collaborative cohort study. Seizure-Eur J Epilep 87: 107-113 doi:10.1016/j.seizure.2021.03.012

39. Rigamonti A, Imbesi F, Silvani A, Gaviani P, Agostoni E, Porcu L, De Simone I, Torri V, Salmaggi A (2018) Antiepileptic treatment and survival in newly diagnosed glioblastoma patients: Retrospective multicentre study in 285 Italian patients. J Neurol Sci 390: 14-19 doi:10.1016/j.jns.2018.04.004

40. Simo M, Velasco R, Graus F, Verger E, Gil M, Pineda E, Blasco J, Bruna J (2012) Impact of antiepileptic drugs on thrombocytopenia in glioblastoma patients treated with standard chemoradiotherapy. J Neuro-Oncol 108: 451-458 doi:10.1007/s11060-012-0836-1

41. Dinapoli L, Maschio M, Jandolo B, Fabi A, Pace A, Sperati F, Muti P (2009) Quality of life and seizure control in patients with brain tumor-related epilepsy treated with levetiracetam monotherapy: preliminary data of an open-label study. Neurol Sci 30: 353-359 doi:10.1007/s10072-009-0087$\mathrm{x}$

42. Fuller KL, Wang YY, Cook MJ, Murphy MA, D'Souza WJ (2013) Tolerability, safety, and side effects of levetiracetam versus phenytoin in intravenous and total prophylactic regimen among craniotomy patients: A prospective randomized study. Epilepsia 54: 45-57 doi:10.1111/j.1528-1167.2012.03563.x

43. Maschio M, Albani F, Baruzzi A, Zarabla A, Dinapoli L, Pace A, Pompili A, Carapella CM, Occhipinti E, Jandolo B (2006) Levetiracetam therapy in patients with brain tumour and epilepsy. J Neuro-Oncol 80: 97-100 doi:10.1007/s11060-006-9162-9

44. Maschio M, Dinapoli L, Sperati F, Pace A, Fabi A, Vidiri A, Muti P (2011) Levetiracetam monotherapy in patients with brain tumor-related epilepsy: seizure control, safety, and quality of life. J Neuro-Oncol 104: 205-214 doi:10.1007/s11060-010-0460-x

45. Newton HB, Goldlust SA, Pearl D (2006) Retrospective analysis of the efficacy and tolerability of levetiracetam in brain tumor patients. J NeuroOncol 78: 99-102 doi:10.1007/s11060-005-9070-4

46. Toledo M, Sarria-Estrada S, Quintana M, Maldonado X, Martinez-Ricarte F, Rodon J, Auger C, Aizpurua M, Salas-Puig J, Santarnarina E, MartinezSaez E (2017) Epileptic features and survival in glioblastomas presenting with seizures. Epilepsy Research 130: 1-6 doi:10.1016/j.eplepsyres.2016.12.013

47. Valko PO, Siddique A, Linsenmeier C, Zaugg K, Held U, Hofer S (2015) Prevalence and predictors of fatigue in glioblastoma: a prospective study. Neuro-Oncology 17: 274-281 doi:10.1093/neuonc/nou127

48. Wychowski T, Wang HY, Buniak L, Henry JC, Mohile N (2013) Considerations in prophylaxis for tumor-associated epilepsy: Prevention of status epilepticus and tolerability of newer generation AEDs. Clin Neurol Neurosur 115: 2365-2369 doi:10.1016/j.clineuro.2013.08.023

49. Jabbarli R, Ahmadipour Y, Rauschenbach L, Santos AN, Darkwah Oppong M, Pierscianek D, Quesada CM, Kebir S, Dammann P, Guberina N, Scheffler B, Kaier K, Stuschke M, Sure U, Wrede KH (2021) How about Levetiracetam in Glioblastoma? An Institutional Experience and MetaAnalysis. Cancers (Basel) 13 doi:10.3390/cancers13153770

50. Toledo M, Sarria-Estrada S, Quintana M, Maldonado X, Martinez-Ricarte F, Rodon J, Auger C, Salas-Puig J, Santamarina E, Martinez-Saez E (2015) Prognostic implications of epilepsy in glioblastomas. Clin Neurol Neurosur 139: 166-171 doi:10.1016/j.clineuro.2015.10.002

51. Verhaak RG, Hoadley KA, Purdom E, Wang V, Qi Y, Wilkerson MD, Miller CR, Ding L, Golub T, Mesirov JP, Alexe G, Lawrence M, O'Kelly M, Tamayo P, Weir BA, Gabriel S, Winckler W, Gupta S, Jakkula L, Feiler HS, Hodgson JG, James CD, Sarkaria JN, Brennan C, Kahn A, Spellman PT, Wilson RK, Speed TP, Gray JW, Meyerson M, Getz G, Perou CM, Hayes DN, Cancer Genome Atlas Research N (2010) Integrated genomic analysis identifies clinically relevant subtypes of glioblastoma characterized by abnormalities in PDGFRA, IDH1, EGFR, and NF1. Cancer Cell 17: 98-110 doi:10.1016/j.ccr.2009.12.020

52. Sturm D, Witt H, Hovestadt V, Khuong-Quang DA, Jones DT, Konermann C, Pfaff E, Tonjes M, Sill M, Bender S, Kool M, Zapatka M, Becker N, Zucknick M, Hielscher T, Liu XY, Fontebasso AM, Ryzhova M, Albrecht S, Jacob K, Wolter M, Ebinger M, Schuhmann MU, van Meter T, Fruhwald MC, Hauch H, Pekrun A, Radlwimmer B, Niehues T, von Komorowski G, Durken M, Kulozik AE, Madden J, Donson A, Foreman NK, Drissi R, Fouladi M, Scheurlen W, von Deimling A, Monoranu C, Roggendorf W, Herold-Mende C, Unterberg A, Kramm CM, Felsberg J, Hartmann C, Wiestler B, Wick W, Milde T, Witt O, Lindroth AM, Schwartzentruber J, Faury D, Fleming A, Zakrzewska M, Liberski PP, Zakrzewski K, Hauser P, Garami M, Klekner A, Bognar L, Morrissy S, Cavalli F, Taylor MD, van Sluis P, Koster J, Versteeg R, Volckmann R, Mikkelsen T, Aldape K, Reifenberger G, Collins VP, Majewski J, Korshunov A, Lichter P, Plass C, Jabado N, Pfister SM (2012) Hotspot mutations in H3F3A and IDH1 define distinct epigenetic and biological subgroups of glioblastoma. Cancer Cell 22: 425-437 doi:10.1016/j.ccr.2012.08.024 
53. Bhat KPL, Balasubramaniyan V, Vaillant B, Ezhilarasan R, Hummelink K, Hollingsworth F, Wani K, Heathcock L, James JD, Goodman LD, Conroy S, Long L, Lelic N, Wang S, Gumin J, Raj D, Kodama Y, Raghunathan A, Olar A, Joshi K, Pelloski CE, Heimberger A, Kim SH, Cahill DP, Rao G, Den Dunnen WFA, Boddeke H, Phillips HS, Nakano I, Lang FF, Colman H, Sulman EP, Aldape K (2013) Mesenchymal differentiation mediated by NFkappaB promotes radiation resistance in glioblastoma. Cancer Cell 24: 331-346 doi:10.1016/j.ccr.2013.08.001

54. Filippini G, Falcone C, Boiardi A, Broggi G, Bruzzone MG, Caldiroli D, Farina R, Farinotti M, Fariselli L, Finocchiaro G, Giombini S, Pollo B, Savoiardo M, Solero CL, Valsecchi MG, Brain Cancer Register of the Fondazione IINCB (2008) Prognostic factors for survival in 676 consecutive patients with newly diagnosed primary glioblastoma. Neuro Oncol 10: 79-87 doi:10.1215/15228517-2007-038

55. Frandsen J, Orton A, Jensen R, Colman H, Cohen AL, Tward J, Shrieve DC, Suneja G (2018) Patterns of care and outcomes in gliosarcoma: an analysis of the National Cancer Database. Journal of Neurosurgery 128: 1133-1138 doi:10.3171/2016.12.Jns162291

56. Sun T, Warrington NM, Luo JQ, Brooks MD, Dahiya S, Snyder SC, Sengupta R, Rubin JB (2014) Sexually dimorphic RB inactivation underlies mesenchymal glioblastoma prevalence in males. J Clin Invest 124: 4123-4133 doi:10.1172/Jci71048

57. Haupt S, Caramia F, Herschtal A, Soussi T, Lozano G, Chen H, Liang H, Speed TP, Haupt Y (2019) Identification of cancer sex-disparity in the functional integrity of p53 and its X chromosome network. Nat Commun 10 doi:ARTN 5385 10.1038/s41467-019-13266-3

58. Tsimberidou AM, Iskander NG, Hong DS, Wheler JJ, Falchook GS, Fu SQ, Piha-Paul S, Naing A, Janku F, Luthra R, Ye Y, Wen SJ, Berry D, Kurzrock R (2012) Personalized Medicine in a Phase I Clinical Trials Program: The MD Anderson Cancer Center Initiative. Clinical Cancer Research 18: 6373-6383 doi:10.1158/1078-0432.Ccr-12-1627

59. Dienstmann R, Rodon J, Tabernero J (2013) Biomarker-driven patient selection for early clinical trials. Curr Opin Oncol 25: 305-312 doi:10.1097/CCO.0b013e32835ff3cb

60. Mansouri A, Hachem LD, Mansouri S, Nassiri F, Laperriere NJ, Xia D, Lindeman NI, Wen PY, Chakravarti A, Mehta MP, Hegi ME, Stupp R, Aldape KD, Zadeh G (2019) MGMT promoter methylation status testing to guide therapy for glioblastoma: refining the approach based on emerging evidence and current challenges. Neuro Oncol 21: 167-178 doi:10.1093/neuonc/noy132

\section{Figures}




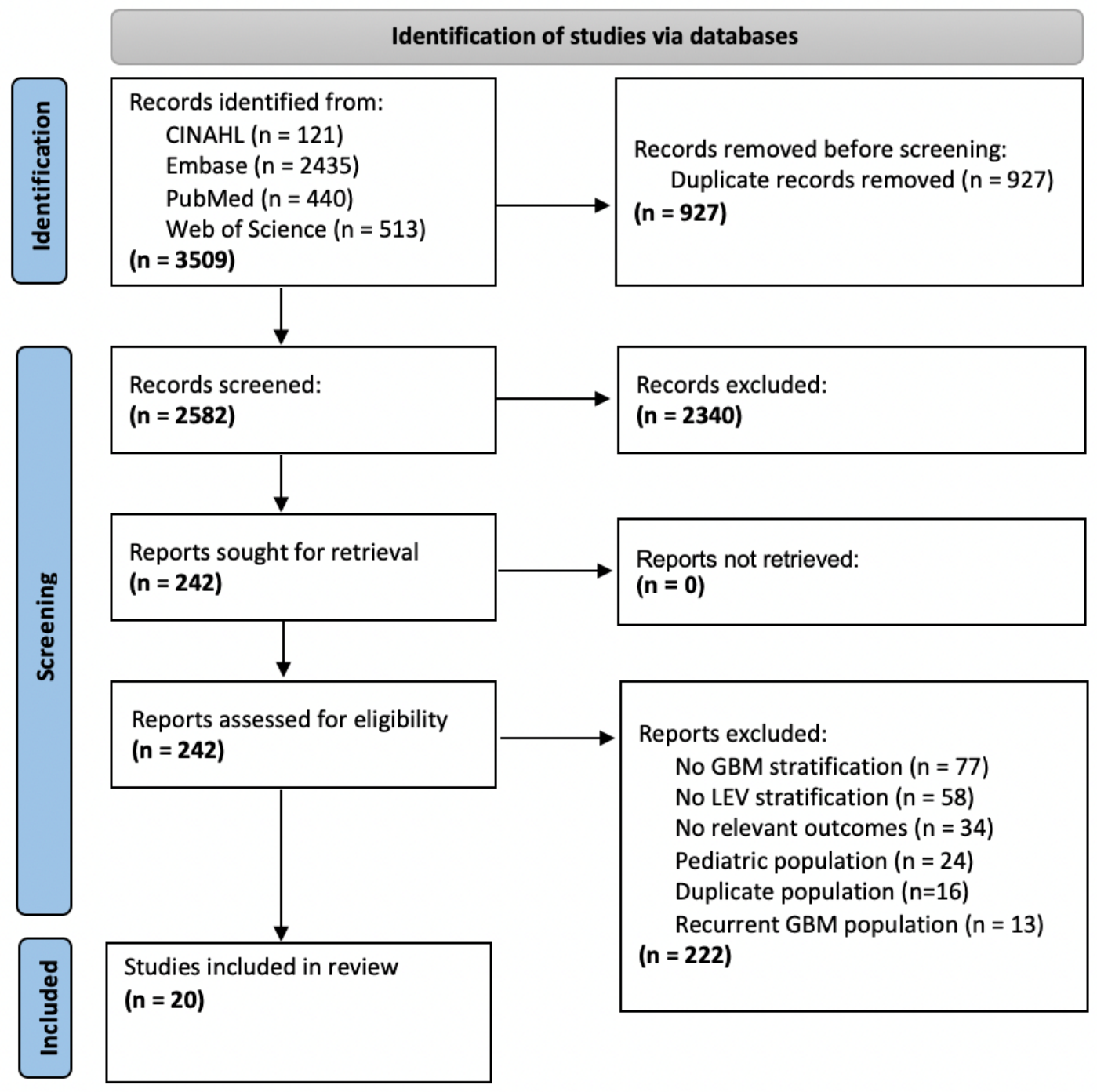

Figure 1

PRISMA flow diagram of search results and study selection. 


\begin{tabular}{|c|c|c|c|c|c|c|c|c|c|c|}
\hline Study & Country & $\begin{array}{l}\text { LEV } \\
\text { Total }\end{array}$ & $\begin{array}{l}\text { No LEV } \\
\text { Total }\end{array}$ & $\log [\mathrm{HR}]$ & SE & & Hazard Ratio & HR & $95 \%-\mathrm{Cl}$ & Weight \\
\hline Kim et al. 2015 & Korea & 58 & 45 & -1.17 & 0.3579 & & — & 0.31 & {$[0.15 ; 0.63]$} & $3.0 \%$ \\
\hline Simo et al. 2012 & Spain & 31 & 70 & -0.76 & 0.7827 & & & 0.47 & {$[0.10 ; 2.18]$} & $0.7 \%$ \\
\hline Ryu et al. 2019 & Korea & 322 & 96 & -0.43 & 0.1242 & & $\mp$ & 0.65 & {$[0.51 ; 0.83]$} & $10.7 \%$ \\
\hline Roh et al. 2020 & Korea & 169 & 153 & -0.37 & 0.1246 & & $\mp$ & 0.69 & {$[0.54 ; 0.88]$} & $10.7 \%$ \\
\hline Berendsen et al. 2016 & Netherlands & 92 & 555 & -0.16 & 0.1642 & & $\because$ & 0.85 & {$[0.62 ; 1.17]$} & $8.5 \%$ \\
\hline Rigamonti et al. 2018 & Italy & 119 & 116 & -0.16 & 0.1428 & & $\div$ & 0.85 & {$[0.64 ; 1.12]$} & $9.6 \%$ \\
\hline Barker et al. 2013 & USA & 92 & 439 & -0.08 & 0.1543 & & $\frac{1}{4}$ & 0.92 & {$[0.68 ; 1.24]$} & $9.0 \%$ \\
\hline Cardona et al. 2018 & Colombia & 78 & 135 & -0.03 & 0.0132 & & +1 & 0.97 & {$[0.94 ; 0.99]$} & $16.6 \%$ \\
\hline Happold et al. 2016 & Europe; NA & 541 & 1041 & 0.05 & 0.0678 & & 낼 & 1.05 & {$[0.92 ; 1.20]$} & $14.3 \%$ \\
\hline Knudsen-Baas et al. 2016 & Norway & 195 & 1068 & 0.15 & 0.1070 & & 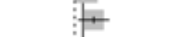 & 1.16 & {$[0.94 ; 1.43]$} & $11.8 \%$ \\
\hline Knudsen-Baas et al. 2021 & Italy; Norway & 71 & 29 & 0.62 & 0.2581 & & $\mp$ & 1.86 & {$[1.12 ; 3.08]$} & $4.9 \%$ \\
\hline \multicolumn{6}{|c|}{ Random effects model } & \multicolumn{2}{|r|}{ i } & \multirow{3}{*}{\multicolumn{2}{|c|}{$0.89[0.78 ; 1.02]$}} & \multirow[t]{3}{*}{$100.0 \%$} \\
\hline \multirow{2}{*}{\multicolumn{6}{|c|}{$\begin{array}{l}\text { Heterogeneity: } I^{2}=75 \%, \tau^{2}=0.0277, p<0.01 \\
\text { Test for overall effect: } z=-1.67(p=0.09)\end{array}$}} & $\Gamma$ & 1 & & & \\
\hline & & & & & & 0.2 & 0.5 & & & \\
\hline
\end{tabular}

A.

\begin{tabular}{|c|c|c|c|c|c|c|c|c|c|c|}
\hline Study & Country & $\begin{array}{l}\text { LEV } \\
\text { Total }\end{array}$ & $\begin{array}{c}\text { No LEV } \\
\text { Total }\end{array}$ & & Mean & Difference & & MD & $95 \%-\mathrm{Cl}$ & Weight \\
\hline Happold et al. 2016 & Europe; NA & 541 & 1041 & & & C. & & -0.78 & {$[-0.85 ;-0.71]$} & $17.2 \%$ \\
\hline Roh et al. 2020 & Korea & 169 & 153 & & & + & & 3.60 & {$[3.24 ; 3.96]$} & $17.2 \%$ \\
\hline Ryu et al. 2019 & Korea & 322 & 96 & & & + & & 5.00 & {$[4.75 ; 5.25]$} & $17.2 \%$ \\
\hline Kim et al. 2015 & Korea & 58 & 45 & & & & 돔 & 9.00 & {$[8.14 ; 9.86]$} & $17.0 \%$ \\
\hline Simo et al. 2012 & Spain & 31 & 70 & & & & 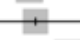 & 9.41 & {$[5.86 ; 12.96]$} & $14.5 \%$ \\
\hline Cardona et al. 2018 & Colombia & 78 & 135 & & & & + & 11.60 & {$[10.57 ; 12.63]$} & $16.9 \%$ \\
\hline \multirow{3}{*}{\multicolumn{4}{|c|}{$\begin{array}{l}\text { Random effects model } \\
\text { Heterogeneity: } I^{2}=100 \%, \tau^{2}=18.1014, p=0 \\
\text { Test for overall effect: } z=3.52(p<0.01)\end{array}$}} & \multicolumn{4}{|c|}{$\sum_{1}^{i}$} & \multirow[t]{3}{*}{6.21} & \multirow[t]{3}{*}[2.75;9.66]{} & \multirow[t]{3}{*}{$100.0 \%$} \\
\hline & & & & 1 & 1 & & & & & \\
\hline & & & & -10 & -5 & 0 & 10 & & & \\
\hline
\end{tabular}

B.

Figure 2

Forest plots of the meta-analysis comparing survival between LEV and no LEV treatment using: (A) Hazard Ratios and (B) The difference in median overall survival. 


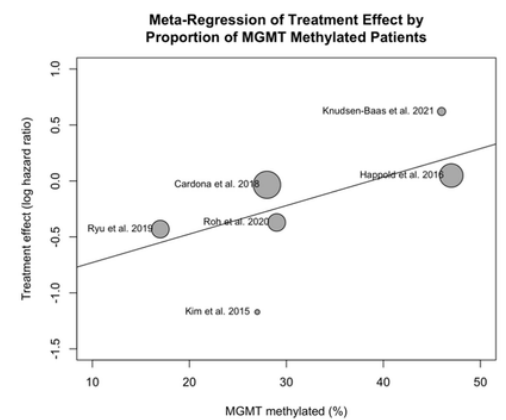

A.

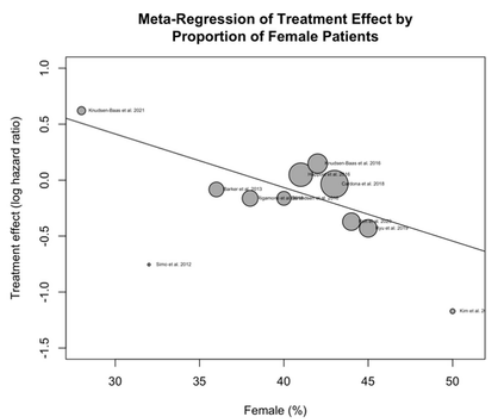

B.

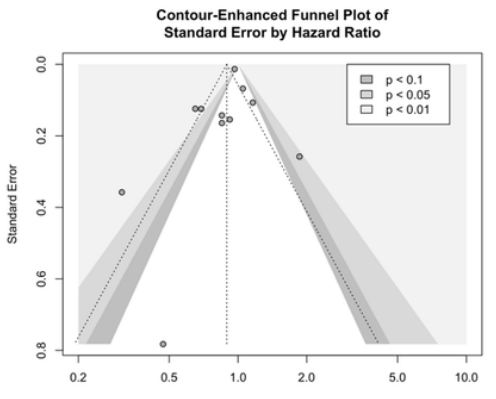

C.

\section{Figure 3}

Evaluation of sources of heterogeneity and publication bias using: Meta-regression analysis of LEV treatment effect with (A) percentage of MGMT methylated patients and (B) female sex as the moderator variable, and (C) Funnel plot of reported LEV treatment according to the standard error. 


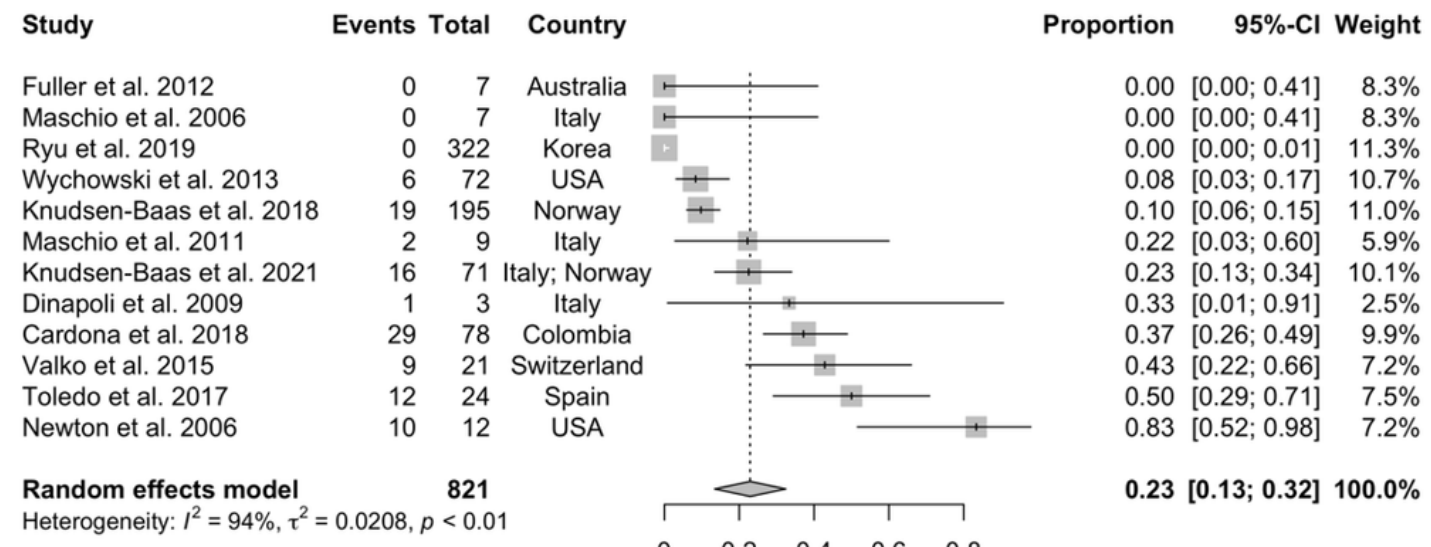

A.

Heterogeneity: $I^{2}=94 \%, \tau^{2}=0.0208, p<0.01$

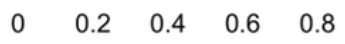

Study

Wychowski et al. 2013

Toledo et al. 2017

Valko et al. 2015

Knudsen-Baas et al. 2018

Cardona et al. 2018

Knudsen-Baas et al. 2021

Fuller et al. 2012

Ryu et al. 2019

Random effects model

Heterogeneity: $I^{2}=55 \%, \tau^{2}=0.2498, p=0.05$

Test for overall effect: $z=-0.82(p=0.41)$

\section{LEV Other AED}

Events Total Events Total

Odds Ratio

\begin{tabular}{|c|c|}
\hline 6 & 72 \\
\hline 12 & 24 \\
\hline 9 & 21 \\
\hline 19 & 195 \\
\hline 29 & 78 \\
\hline 16 & 71 \\
\hline 0 & 7 \\
\hline 0 & 322 \\
\hline & 790 \\
\hline & $=0.05$ \\
\hline
\end{tabular}

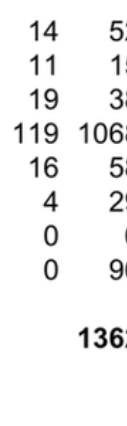

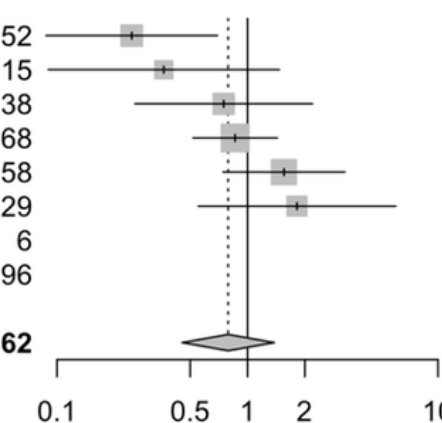

0.1
OR $\quad 95 \%-\mathrm{Cl}$ Weight

$0.25[0.09 ; 0.70] \quad 15.3 \%$

$0.36[0.09 ; 1.47] \quad 10.7 \%$

$0.75[0.26 ; 2.19] 14.7 \%$

$0.86[0.52 ; 1.43] \quad 25.5 \%$

$1.55[0.74 ; 3.24] \quad 20.7 \%$

$1.82[0.55 ; 6.00] \quad 13.1 \%$

$0.0 \%$

$0.0 \%$

B.

Figure 4

Forest plots of the meta-analysis evaluating the safety profile of LEV treatment in GBM using: (A) The pooled prevalence of adverse events during LEV treatment and (B) The pooled odds ratio comparing the likelihood of adverse events with LEV treatment as opposed to other AED treatment.

\section{Supplementary Files}

This is a list of supplementary files associated with this preprint. Click to download.

- LevetiracetamMetaAnalysisSupplementaryMaterialsv1.docx 